\title{
Sosialisasi Pemanfaatan Air Tanah Untuk Lahan Pertanian dengan Metode JIAT Daerah Pallantikang, Kabupaten Bantaeng
}

\author{
Adi Tonggiroh ${ }^{1 *}$, A.M. Imran ${ }^{1}$, Adi Maulana ${ }^{1}$, Meutia Farida ${ }^{1}$, Asri \\ Jaya $^{1}$, Jamal Rauf Husain ${ }^{1}$, Rohaya Langkoke ${ }^{1}$, Ratna Husain ${ }^{1}$, Sultan ${ }^{1}$, \\ Hendra Pachri ${ }^{1}$, Syafruddim ${ }^{1}$, Bahrul Hidayah ${ }^{1}$, Baso Rezki Maulana ${ }^{1}$. \\ Muhammad Sulhuzair Burhanuddin ${ }^{1}$ \\ Departemen Teknik Geologi, Fakultas Teknik Universitas Hasanuddin ${ }^{1}$ \\ adi_unhas@yahoo.com*
}

\begin{abstract}
Abstrak
Air sebagai sumber daya alam merupakan bagian terpenting bagi manusia dalam dalam melangsungkan hidup. Salah satu contoh peranan vital sumber daya air bagi aktivitas manusia yaitu untuk pemenuhan pangan melalui bidang pertanian dan perkebunan. Ketersediaan kebutuhan air untuk produktivitas pertanian tentunya menjadi kajian penting untuk dapat mempertahankan kemampuan suplai dan menghindari krisis bahan pangan hasil pertanian dan perkebunan. Sebagaimana diamanatkan oleh UU Sumber Daya Air, pendayagunaan sumber daya air ditujukan untuk memanfaatkan sumber daya air secara berkelanjutan dengan mengutamakan pemenuhan kebutuhan pokok kehidupan masyarakat secara adil. Demi keberlangsungan kehidupan manusia tersebut, maka sumber daya air harus dikelola dengan baik dengan memperhatikan dan menjaga lingkungannya. Area pertanian dan perkebunan di daerah Pallantikang hampir tidak semuanya memiliki aliran irigasi yang memanfaatkan air permukaan. Konsekuensinya, produksi pertanian tidak mencapai hasil maksimal, karena kebutuhan airnya sangat bergantung pada air hujan. Di sisi lain meskipun terdapat jaringan irigasi, terdapat area-area yang ketersediaan airnya tidak mencukupi, sehingga aktivitas bercocok tanam petani tidak dapat memperoleh hasil yang maksimal. Keterbatasan ini menyebabkan petani ketergantungan akan suplai air permukaan terutama saat musim hujan sehingga permasalahan seperti kemarau berkepanjangan dapat berakibat fatal. Salah satu usaha dalam upaya meningkatkan irigasi pertanian adalah dengan membuat jaringan irigasi air tanah dengan pengambilan air dari sumur bor.
\end{abstract}

Kata Kunci: Pengabdian Masyarakat; Air Tanah; Irigasi; Pertanian; Hidrogeologi.

\begin{abstract}
Water as a natural resource is the most important part for humans to continue their life. One example of the vital role of water resources for human activities is to fulfill food through agriculture and plantations. The availability of water needs for agricultural productivity is certainly an important study to maintain supply capacity and avoid crises in agricultural and plantation foodstuffs. As mandated by the Water Resources Law, the utilization of water resources is aimed at sustainably utilizing water resources by prioritizing the fulfillment of the basic needs of the community fairly. For the sake of the continuity of human life, water resources must be managed properly by paying attention to and protecting the environment. Almost not all the agricultural and plantation areas in the Planting area have irrigation channels that utilize surface water. Consequently, agricultural production does not reach maximum results, because its water needs are very dependent on rainwater. On the other hand, even though there is an irrigation network, there are areas where the availability of water is not sufficient so that farming activities of farmers cannot get maximum results. This limitation causes farmers to depend on surface water supply, especially during the rainy season so that problems such as prolonged drought can have fatal consequences. One of the efforts to improve agricultural irrigation is to create a groundwater irrigation network by taking water from bore wells.
\end{abstract}

Keywords: Community Service; Groundwater; Irrigation; Agriculture; Hydrogeology.

\section{Pendahuluan}

Program Pengabdian kepada Masyarakat Fakultas Teknik Tahun 2020 ini, merupakan kelanjutan dari Program Iptek bagi Masyarakat (IbM) yang telah dilaksanakan oleh LP2M Unhas secara berkesinambungan sejak Tahun 2014 di Kota Parepare, Sinjai, Makassar, Gowa 
dan Watampone.

Rencana Pembangunan Jangka Menengah Daerah (RPJMD) Provinsi Sulawesi Selatan Tahun 2018-2023 adalah kerangka kebijakan daerah yang perlu didukung oleh seluruh komponen masyarakat, khususnya Universitas Hasanuddin sebagai Perguruan Tinggi Negeri terbesar di Kawasan Timur Indonesia. Visi RPJMD Provinsi Sulawesi Selatan periode 2018-2023 adalah "Sulawesi Selatan yang Inovatif, Produktif, Kompetitif, Inklusif, dan Berkarakter". Rumusan visi ini mengandung lima pokok visi di dalamnya yakni inovatif, produktif, kompetitif, inklusif dan berkarakter. Keempat pokok visi ini merupakan rangkaian yang terkait satu sama lain dalam mewujudkan kondisi pada tahun 2023 dimana terjelmakan provinsi Sulawesi Selatan yang "Bersih dan Melayani", "Terkoneksi", "Mandiri dan Sejahtera", "Sehat dan Cerdas" serta "Berkarakter". Air sangat dibutuhkan sebagai sumber kehidupan manusia dalam kelangsungan hidupnya. Kebutuhan air tersebut, tidak saja diperlukan bagi aktivitas manusia, namun juga untuk pemenuhan akan pangan melalui bidang pertanian dan perkebunan. Ketersediaan kebutuhan air untuk produktivitas pertanian, tentunya menjadi kajian penting untuk dapat mempertahankan kemampuan suplai dan menghindari krisis bahan pangan hasil pertanian dan perkebunan. Sebagaimana diamanatkan oleh UU Sumber Daya Air, pendayagunaan sumber daya air ditujukan untuk memanfaatkan sumber daya air secara berkelanjutan dengan mengutamakan pemenuhan kebutuhan pokok kehidupan masyarakat secara adil. Demi keberlangsungan kehidupan manusia tersebut, maka sumber daya air harus dikelola dengan baik dengan memperhatikan dan menjaga lingkungannya. (Tim Penyusun RPJMD, 2018)

Area pertanian dan perkebunan di suatu daerah hampir tidak semuanya memiliki aliran irigasi yang memanfaatkan air permukaan. Konsekuensinya, produksi pertanian tidak mencapai hasil maksimal, karena kebutuhan airnya sangat bergantung pada air hujan. Di sisi lain, meskipun terdapat jaringan irigasi, namun terdapat area-area yang ketersediaan airnya tidak mencukupi, sehingga petani tidak dapat secara maksimal bercocok tanam. Keterbatasan ini terkadang menyebabkan petani hanya mampu bercocok tanam setahun sekali dan terkadang tidak sama sekali terutama bila terjadi kemarau berkepanjangan. (Bouwer, H. 1978)

Sektor pertanian merupakan salah satu sumber penghasilan terbesar di beberapa kabupaten di Sulawesi Selatan utamanya tanaman padi, namun areal persawahan yang ada hanya mengandalkan curah hujan. Salah satu usaha dalam upaya meningkatkan irigasi pertanian adalah dengan membuat Jaringan Irigasi Air Tanah (JIAT) dengan pengambilan air dari sumur bor. (Camppbell, M.D. and Lehr, J.H. 1974). Kontribusi mitra dalam kegiatan ini sangat penting dalam memfasilitasi, mengkoordinasikan dan membantu mensosialisasikan/memberi pemahaman lebih dalam kepada petani-petani sebagai pelaku kegiatan pertanian di Kelurahan Pallantikang, Kabupaten Bantaeng.

Misi peningkatan daya saing daerah yang diamanatkan dalam RPJM harus dilaksanakan, termasuk untuk prioritas bidang pendidikan 20\% dan kesehatan $10 \%$ sesuai ketentuan teknis yang berlaku. Program Kelompok Prioritas Pertama (KP I) terdiri dari kebijakan prioritas yang antara lain memuat peningkatan kualitas dan kapasitas masyarakat khususnya pihak-pihak yang terkait sektor pertanian. 


\section{Latar Belakang dan Permasalahan Mitra}

Dari berbagai ulasan di atas dan melihat fenomena yang berkembang di masyarakat khususnya kalangan petani dan pihak yang terkait langsung dengan kegiatan pertanian, maka dapat disimpulkan permasalahan yang dialami oleh Mitra adalah sebagai berikut;

1. Penerapan dan pemahaman akan Earth Science atau Ilmu Kebumian kurang familiar dan sulit dipahami oleh masyarakat karena kurang optimalnya sosialisasi dan pembelajaran berbasis earth science pada lembaga pendidikan formal maupun non-formal, serta minimnya literatur yang menggunakan bahasa Indonesia.

2. Minimnya pemahaman/gambaran masyarakat umum akan pemanfaatan/ pengaplikasian ilmu kebumian dalam kehidupan sehari-hari khususnya di sektor pertanian.

3. Fenomena kemarau panjang dan terbatasnya pasokan air untuk memenuhi kebutuhan irigasi serta kemajuan teknologi khususnya di bidang pertanian yang semakin pesat memerlukan sosialisasi dan pemberian pemahaman ilmu kebumian yang terarah khususnya yang berkaitan langsung dengan hidrogeologi, pemetaan dan contoh pengaplikasiannya dalam peningkatan pertanian salah satu bentuk pengaplikasiannya yaitu Perencanaan Sistem Jaringan Irigasi Air Tanah yang digunakan sebagai alternatif pengganti irigasi konvensional dan juga sebagai salah satu bentuk penanggulangan terhadap kondisi krisis air bersih akibat perubahan iklim dan cuaca yang ekstrim. (Fletcher G. Driscoll. 1987)
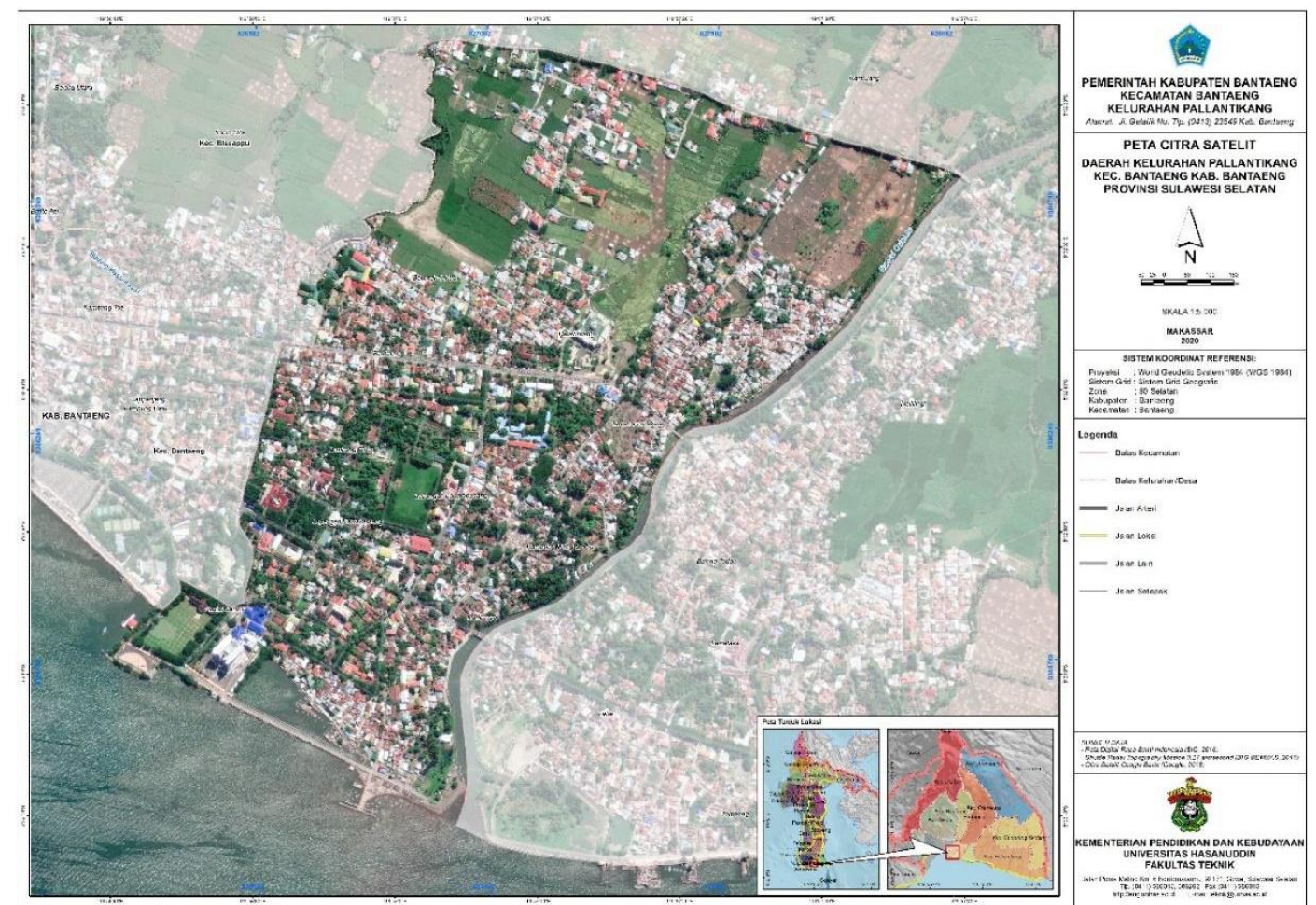

Gambar 1. Kondisi geografis dan batas administrasi Daerah Kelurahan Pallantikang ditinjau dari udara (Sumber Data: Peta Citra Satelit, Terbitan Google Tahun 2018) 


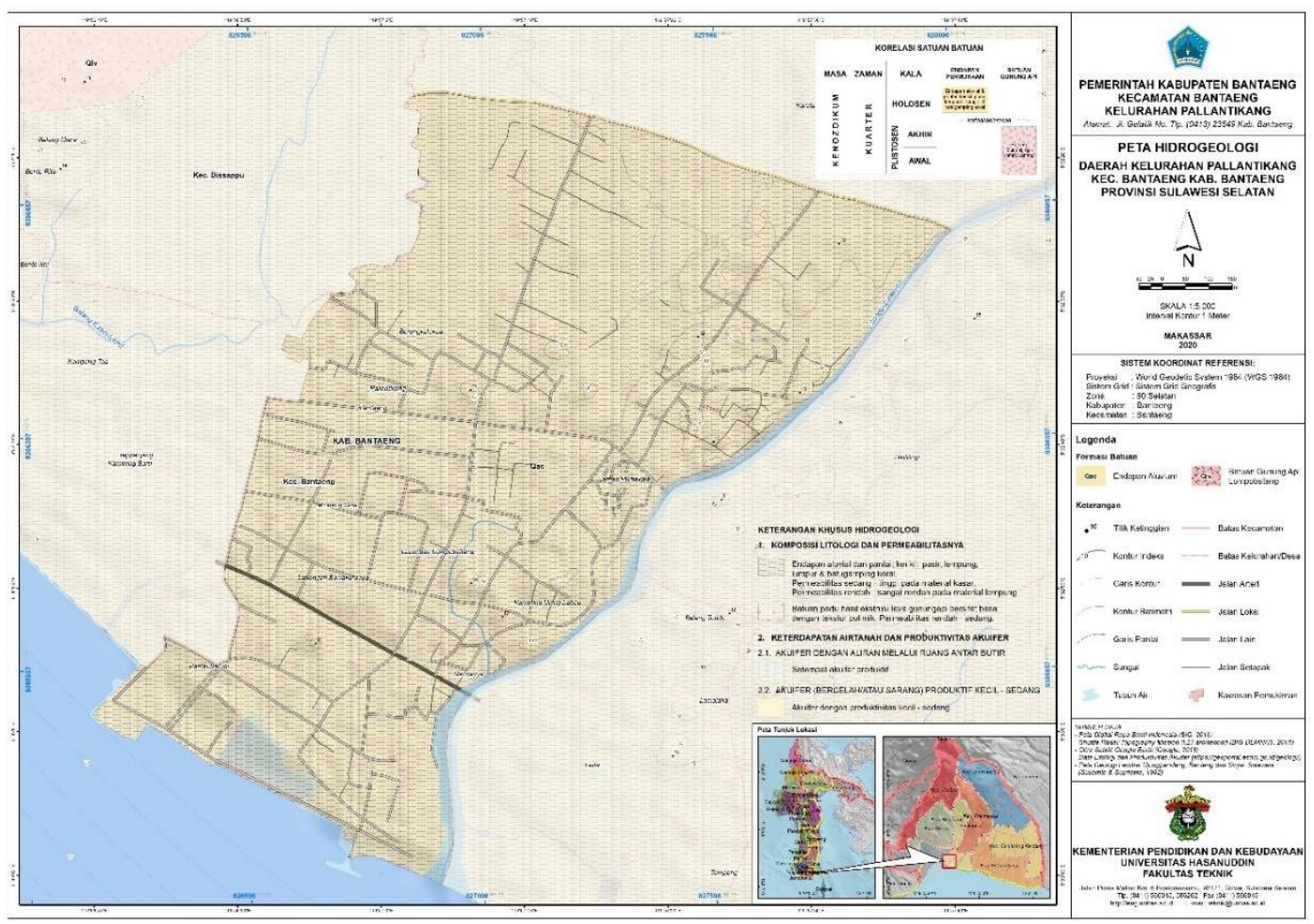

Gambar 2. Lokasi studi pada Peta Hidrogeologi Indonesia skala 1:250.000 (sumber data: https://geoportal.esdm.go.id/indonesia-overview/)
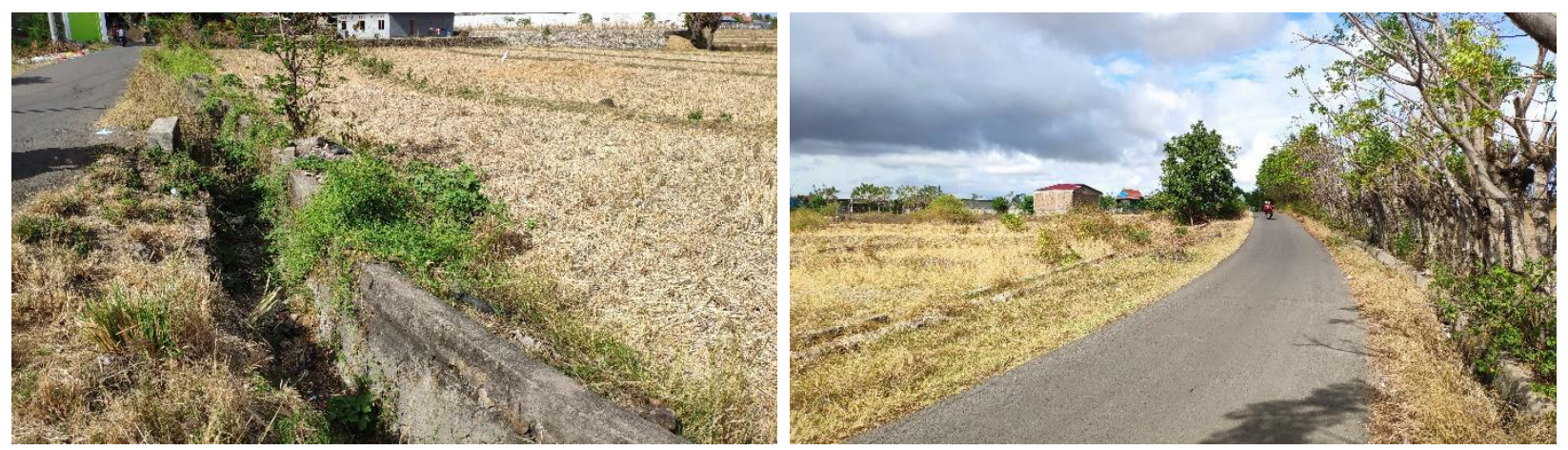

Gambar 3. Kondisi bangunan air dan lahan persawahan lokasi studi di musim kemarau

\section{Metode Pelaksanaan dan Solusi yang Ditawarkan}

Pelatihan dan sosialisasi mengenai dasar-dasar geologi; Pelatihan/pengenalan instrumen yang digunakan untuk survei hidrogeologi (pendugaan kondisi akuifer) berupa alat resistivity meter, survei lahan (pemetaan topografi area layanan irigasi), dan pembuatan rancangan sistem jaringan irigasi air tanah; Pengenalan dasar-dasar Sistem Informasi Geografis baik dalam bentuk demonstrasi dan hasil layout berupa peta kepada aparatur desa/kelurahan serta perwakilan petani (kelompok tani) di Kelurahan Pallantikang, Kabupaten Bantaeng, Sulawesi Selatan. 


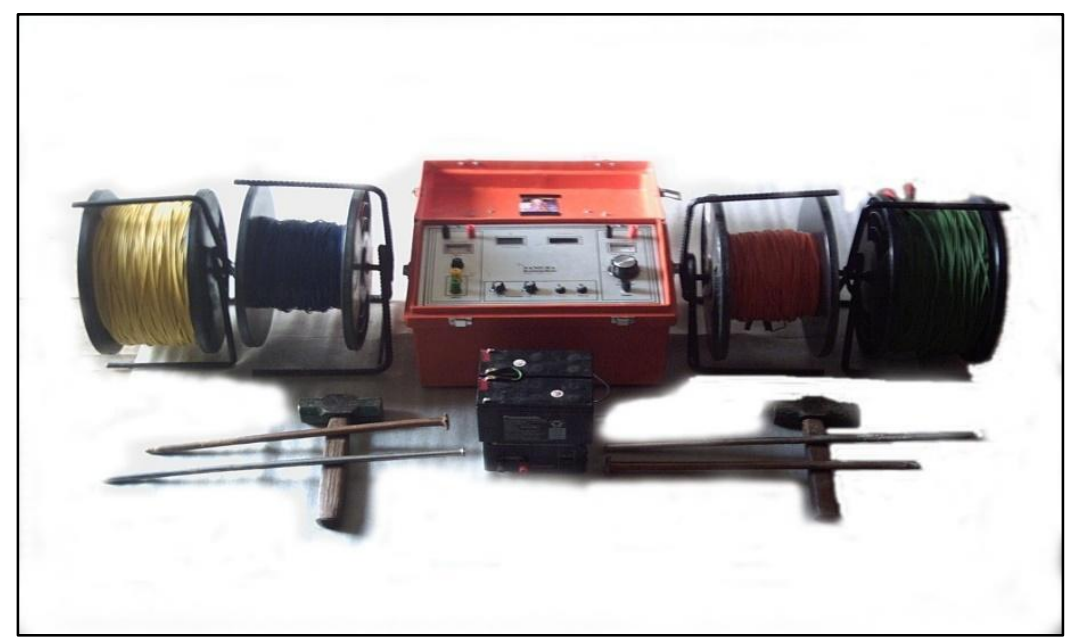

Gambar 4. Peralatan Geolistrik tahanan jenis yang terdiri dari: Resistivity Meter NRD-300 Hf, Roll Kabel ; ( 2 x 500 m, 2 x 100 m), Power Source (accu kering 2 x 12 volt), Elektroda Potensial 2 buah, elektroda arus 2 buah dan Palu (HAGI. 1983)

Metode demonstrasi dilakukan dengan memperlihatkan secara langsung contoh kegiatan survei hidrogeologi menggunakan resistivity meter, pengukuran geodesi dan analisis topografi menggunakan GPS dan photogrammetry, pembuatan peta serta perencanaan sistem Jaringan Irigasi Air Tanah berdasarkan data-data geologi tersebut di laboratorium remote sensing dan pemodelan di departemen Teknik Geologi Universitas Hasanuddin. Selain itu, juga diperkenalkan sistem informasi geografis (SIG) untuk memberi sedikit gambaran perkembangan ilmu pengetahuan dan teknologi seputar kebumian secara terpadu.

Dari berbagai permasalahan yang dihadapi oleh mitra dalam hal ini petani dan pihak yang terkait langsung dalam pertanian seperti tersebut di atas, maka kami selaku pengemban Tri Dharma Perguruan Tinggi yang salah satunya adalah kegiatan Pengabdian kepada Masyarakat, berusaha menawarkan solusi dari persoalan yang timbul beberapa tahun terakhir, yaitu:

1. Memberikan pelatihan dalam bentuk sosialisasi mengenai dasar-dasar geologi, meliputi; bagaimana batuan tersebut terbentuk di alam, sistem akuifer (lapisan batuan yang dapat menyimpan dan meloloskan air, formasi geologi yang terdiri atas batuan sarang yang mengandung air dengan batuan lolos (pasir atau kerikil) yang mampu mengalirkan air dalam jumlah yang berarti) pada suatu daerah yang dapat dimanfaatkan untuk memenuhi kebutuhan irigasi pertanian, serta proses-proses sedimentologi dan ilmu dasar lainnya yang terkait dengan pertanian. (Boonstra, J. 1999)

2. Pelatihan/pengenalan instrumen yang digunakan untuk survei hidrogeologi (pendugaan kondisi akuifer), survei lahan (pemetaan topografi area layanan irigasi), dan pembuatan rancangan sistem jaringan irigasi air tanah. (Fletcher G. Driscoll., 1987).

3. Pengenalan dasar-dasar Sistem Informasi Geografis baik dalam bentuk demonstrasi dan hasil layout berupa peta. ( Irvan, dkk., 2019).

4. Diskusi dari semua permasalahan yang dihadapi mitra.

5. Kunjungan lapangan, untuk memahami lebih jauh kondisi geologi di lapangan.

Segala upaya pelatihan tersebut di atas merupakan cara paling efektif untuk mentransfer ilmu pengetahuan dan pemahaman aplikasinya khususnya di sektor pertanian. Dengan demikian, melalui kegiatan ini diharapkan dapat meningkatkan kapasitas masyarakat khususnya pihak yang 
berkaitan dengan pertanian dalam optimalisasi pemanfaatan air tanah untuk pertanian. Kegiatan pelatihan ini bila dilakukan secara berkesinambungan akan meningkatkan pemahaman tentang geologi, khususnya bidang hidrogeologi, yang tidak mereka dapatkan di bangku pendidikan formal dan lebih memudahkan mereka dalam memahami fungsi/peranan materi ilmu kebumian pada sektor pertanian khususnya yang berkaitan dengan pemanfaatan air tanah untuk kebutuhan irigasi dan peningkatan hasil pertanian.

Berbagai permasalahan dihadapi oleh masyarakat dalam memahami ilmu kebumian, dan tugas para ahli Geologi untuk membantu mereka dengan melakukan sosialisasi dan pelatihanpelatihan, salah satu kerja nyata pengabdian kepada masyarakat yang akan kami laksanakan di Kelurahan Pallantikang, Kabupaten Bantaeng, Provinsi Sulawesi Selatan.

Untuk itu diperlukan partisipasi seluruh aparatur desa/kelurahan terkait serta beberapa perwakilan petani (kelompok tani) untuk mengikuti kegiatan pelatihan tersebut

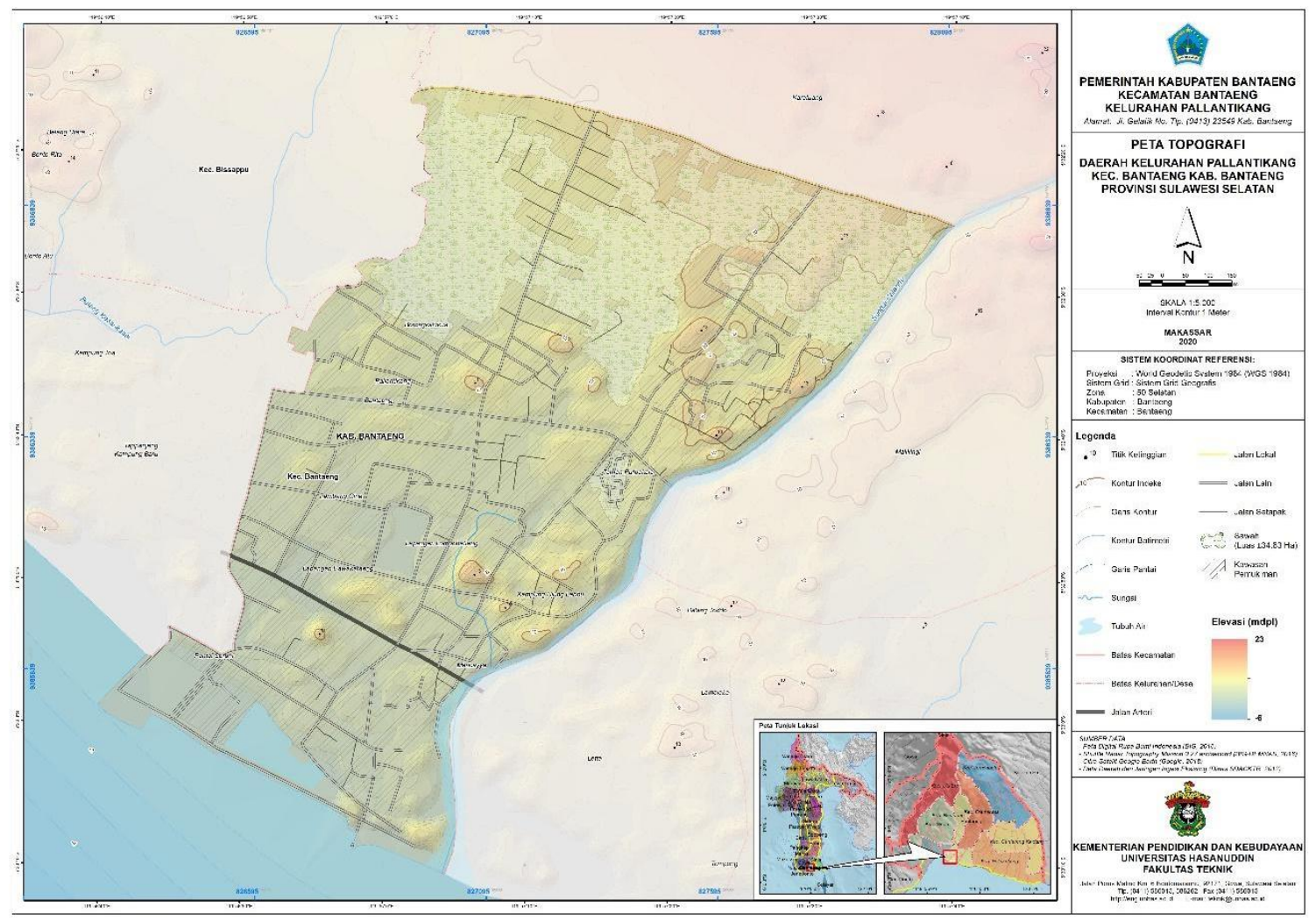

Gambar 5. Kondisi topografi dan kemiringan lereng pada lokasi studi (Sumber Data: Peta Digital Rupa Bumi Indonesia Skala 1:50.000, Terbitan BIG Tahun 2016)

Target dari kegiatan pengabdian kepada Masyarakat ini adalah sebagai berikut:

1. Peningkatan kapasitas keilmuan baik aparatur desa/kelurahan maupun beberapa perwakilan petani.

2. Menambah pemahaman aparatur desa/kelurahan maupun beberapa perwakilan petani tentang pentingnya ilmu kebumian seperti aspek hidrogeologi dan topografi untuk perencanaan Sistem Jaringan Irigasi Air Tanah.

3. Para aparatur desa/kelurahan maupun beberapa perwakilan petani lebih memahami potensi sumberdaya alam khususnya kondisi hidrogeologi dan topografi daerah mereka. 
Pelaksanaan Sosialisasi Pemanfaatan Air Tanah Untuk Lahan Pertanian dengan Metode JIAT Daerah Kelurahan Pallantikang Kabupaten Bantaeng Provinsi Sulawesi Selatan dirancang sedemikian rupa dalam bentuk mekanisme rancangan kegiatan sebagai berikut:

A. Identifikasi masalah

Mempelajari dan menghimpun informasi sebanyak-banyaknya tentang permasalahan yang dihadapi oleh Mitra dalam hal ini aparatur desa/kelurahan serta petani di Kelurahan Pallantikang Kabupaten Bantaeng. Setelah itu, dirumuskan Judul kegiatan, dilanjutkan dengan berkomunikasi dengan pihak Mitra, kemudian penyusunan proposal Pengabdian Kepada Masyarakat.

B. Rencana kegiatan

Rencana kegiatan pelatihan meliputi persiapan sebagai berikut:

- Departemen Teknik Geologi membuat surat penugasan kepada Tim Pelaksana Pelatihan yang terdiri dari 11 orang dosen, 3 mahasiswa, dan 1 orang tenaga administrasi.

- Ketua Tim berkoordinasi dengan mitra yang dipimpin oleh Lurah Pallantikang Kabupaten Bantaeng. untuk mendata jumlah Kelompok Tani dan Petani, untuk membuat persiapan undangan dan materi pelatihan.

- Ketua pelaksana melakukan rapat persiapan untuk pembagian tugas kepada anggota Tim, yang meliputi persiapan materi serta persiapan pelaksanaan sosialisasi dan pelatihan.

- Merancang waktu pelaksanaan pelatihan bersama dengan aparatur desa/kelurahan serta perwakilan petani (kelompok tani) peserta sosialisasi dan pelatihan.

C. Pelaku kegiatan

Pemateri adalah tenaga dosen Program Studi Teknik Geologi dibantu 3 orang mahasiswa (asisten), sedangkan peserta yang terlibat dalam kegiatan pelatihan adalah aparatur desa/kelurahan serta perwakilan petani (kelompok tani) di Kelurahan Pallantikang, Kabupaten Bantaeng, Sulawesi Selatan. Materi dalam bentuk modul, slide presentasi, dan pengenalan beberapa instrumen terkait survei dan perencanaan sistem Jaringan Irigasi Air Tanah. 


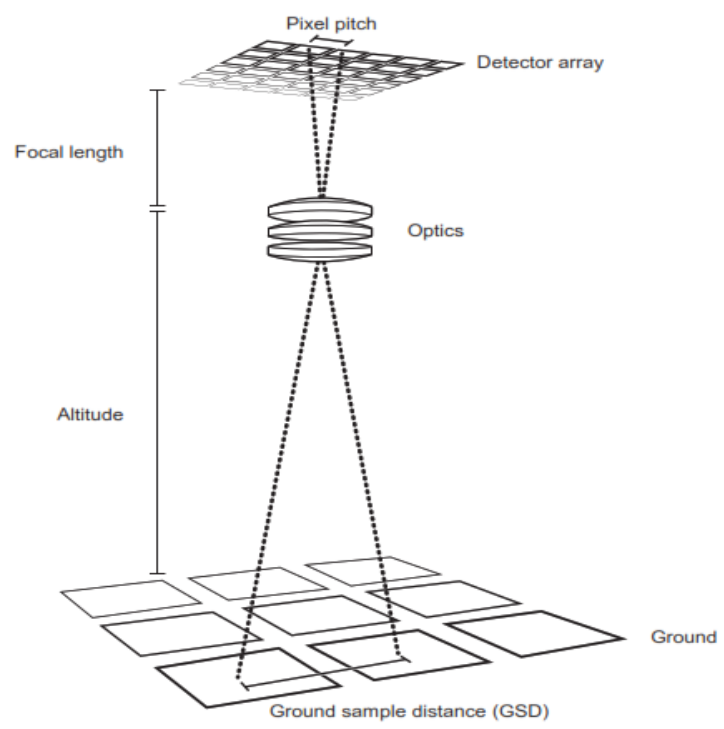

Gambar 6. Sistem kerja pengambilan data foto udara untuk pemetaan areal menggunakan drone (Cahyono, A.B. dan Duantari, N. 2017)
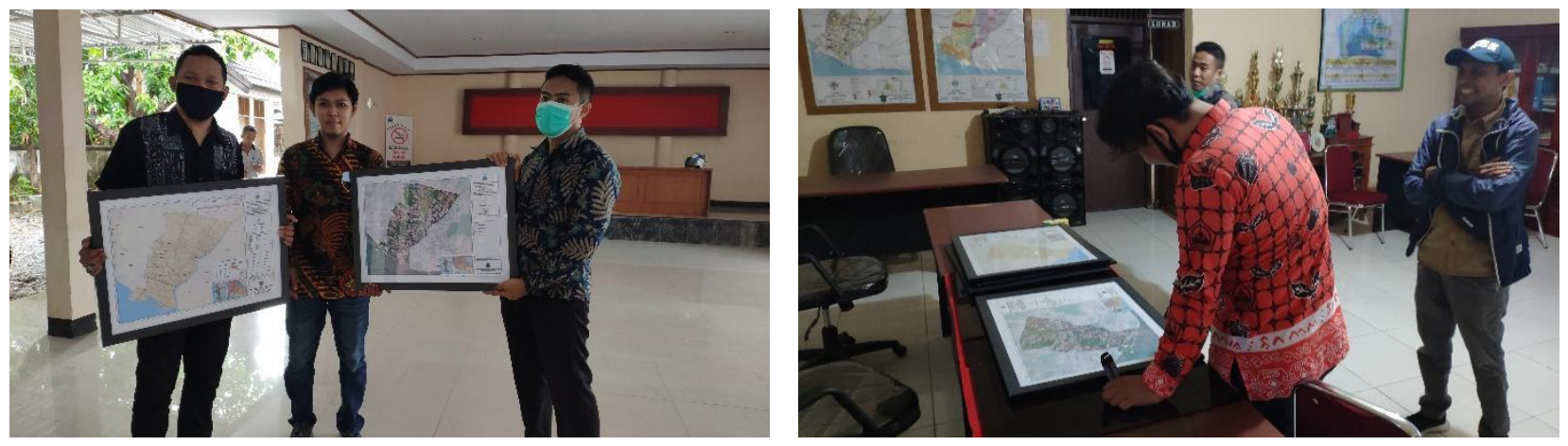

Gambar 7. Pelaksanaan kegiatan sosialisasi dan penyerahan materi dan produk peta kepada pemerintah dan ketua kelompok tani setempat

\section{Hasil dan Diskusi}

Proses pelaksanaan kegiatan pengabdian nantinya melibatkan masyarakat setempat dari elemen masyarakat umum dan aparat desa. Peserta latih mengikuti proses pelaksanaan kegiatan dengan tingkat penyerapan materi optimal melalui pengujian simulasi konsep JIAT. Selain itu, data pendukung tingkat penyerapan materi juga diperoleh dari wawancara setelah kegiatan terkait materi pelatihan yang telah diberikan. Produk peta dan perencanaan sistem JIAT dihasilkan berdasarkan data dan informasi eksisting, topografi, Analisa citra dan pengujian geolistrik. Tim pelaksana memberikan penjelasan dan pendampingan selama proses penyusunan dan pembuatan rencana desain JIAT. Selain itu, atas inisiatif masyarakat setempat, melalui koordinasi pemerintah setempat, tim pelaksana untuk implementasi JIAT telah dibentuk yang beranggotakan Kelompok tani yang juga merupakan peserta latih tersebut. 


\section{Kesimpulan}

Masyarakat yang mayoritas berprofesi petani pada daerah Pallantikang Kabupaten Bantaeng jadi lebih memahami tentang pemanfaatan air tanah sebagai sumber air untuk keperluan irigasi, yang nantinya bisa meningkatkan produktifitas pertanian di daerah tersebut baik dari segi kuantitas maupun kualitas, meningkatkan pemahaman aparatur desa/kelurahan maupun beberapa perwakilan petani tentang pentingnya ilmu kebumian, terutara aspek hidrogeologi dan topografi dalam merancang dan mendesain Sistem Jaringan Irigasi Air Tanah. Diharapkan kedepannya kelompok-kelompok tani semakin antusias dalam mengaplikasikan sistem JIAT untuk peningkatan produktivitas lahan pertanian.

\section{Ucapan Terima Kasih}

Ucapan Terima kasih diucapkan kepada Hibah dari Skim LBE pengabdian kepada Masyarakat Fakultas Teknik 2020 yang telah membiayai kegiatan ini, terima kasih kepada Departemen Teknik Geologi yang telah memberi dukungan. Selain itu, ucapan terima kasih juga disampaikan kepada Pemerintah Kabupaten Bantaeng khususnya Daerah Pallantikang, warga masyarakat yang telah berpartisipasi dan seluruh tim pengabdian yang telah menyukseskan kegiatan ini.

\section{Daftar Pustaka}

Badan Standardisasi Nasional, 1998. SNI Penyusunan Peta Geologi nomor 13-4691-1998. Jakarta: BSN.

Boonstra, J. 1999. Well, Hydraulic and Aquifer Test. In HandBook of Groundwater Engineering. Delleur, J. CRC Press LLC. Boca Raton, FL, USA.1999. Well Design and Construction In HandBook of Groundwater Engineering. Delleur, J. CRC Press LLC. Boca Raton, FL, USA.

Bouwer, H. 2014. Groundwater Hydrology pb Edition. McGraw-Hill Book Company, New York.

Cahyono, A.B. dan Duantari, N. 2017. Analisis Ketinggian DSM Pada Data LiDAR. Jurnal Geoid. 12:181-189.

Camppbell, M.D. and Lehr, J.H. 1974. Water Well Technology, National Water Well Association. McGraw-Hill Book Company, New York, 681 p.

DEMNAS-BIG. 2017. Data Digital Elevation Model: Shuttle Radar Topography Mission (DEMSRTM) Resolusi 0,27 arc/second, Lembar 2011-643 EGM v1.0. Bogor: Badan Informasi Geospasial.

Driscoll, F.G. 2001. Groundwater and Wells. Jilid Ketiga (III). Edward E. Johnson Inc., St. Paul, Minnesota, USA. 1089 pages

Fletcher G. Driscoll. 1987. Groundwater and Wells. Minnesota : H.M. Smyth Company, Inc. Fontana, M.G. 1986. Corrosion Engineering. Jilid Ketiga (III). New York: McGraw-Hill Book Company.

HAGI. 1983. Seminar PIT HAGI, Pertemuan Ilmiah Tahunan Himpunan Ahli Geofisika Indonesia, Bandung

Irvan, U.R., Alimuddin, I., Farida, M., Maulana, A., Jaya, A., Sirajuddin. H., Tonggiroh, A., Azikin, B., Sahabuddin. 2019. Implementasi Student Centered Learning (SCL) Materi Olimpiade Sains Nasional (OSN) Kebumian Di SMA Negeri 8 Gowa, Sulawesi Selatan. Jurnal TEPAT. Vol 2, No 2.

Tim Penyusun RPJMD, 2018, Rancangan Awal Rencana Pembangunan Jangka Menengah Daerah Sulawesi Selatan, Makassar. 